\title{
ポーラスコンクリートの乾燥収縮特性とその幾何学モデルに関する研究 STUDY ON DRYING SHRINKAGE CHARACTERISTICS OF POROUS CONCRETE AND ITS GEOMETRICAL MODEL
}

\author{
張 茂 剛*, 三島 直 生 ${ }^{* *}$, 畑 中 重 光*** \\ Maogang ZHANG, Naoki MISHIMA and Shigemitsu HATANAKA
}

\begin{abstract}
In this study, a series of experiments on drying shrinkage of porous concrete was carried out to examine the influence of various factors, i.e. void ratio, rock type and size of aggregates, compaction strength level, etc. It was found that the influence of designed void ratio and rock type of the aggregate on the final amount of drying shrinkage of the porous concrete was significant, while the effect of compaction strength level was insignificant. Based on the experimental results, a geometrical model of the porous concrete was proposed to represent the drying shrinkage characteristics. It seems possible to predict the influence of the various factors on the drying shrinkage characteristics by using the proposed model.
\end{abstract}

Keywords : Porous concrete, Drying shrinkage, Geometrical model, Particle size, Paste thickness, Volume ratio of binder-aggregate ポーラスコンクリート, 乾燥収縮, 幾何学モデル, 粒径, ペースト膜厚, 結合材骨材容積比

\section{1. はじめに}

ポーラスコンクリートは，その内包寸る多量の連続空隙により， 透水性や保水・揚水性といった普通コンクリートにはない様々な性 能を持つことが注目され，既に多方面において実用化が進められて いる 1)。その利用先は, 環境負荷低減や環境共生を目的としたもの が多く，施工実績も増加しつつある。

筆者らはこれまでに，ポーラスコンクリートの乾燥収縮特性に関 する研究 2),3)を行い, その基礎的な乾燥収縮特性を把握するととも に，結合材の乾燥収縮が骨材に拘束され，ひび割れが生じたことよ り，ポーラスコンクリートの圧縮強度および弾性係数が低下寸る可 能性があることを確認した 4)。しかし，ポーラスコンクリートの乾 燥収縮特性に関する研究 5),6) はまだ少なく，その特性が使用性およ び而久性に及ぼす影響など, 不明な点が多い。このため, 工学的に 信頼性の高い設計・施工を行うには, 今後, ポーラスコンクリート の乾燥収縮特性を明らかにすることが望まれる。

一方，普通コンクリートの場合，乾燥収縮はひび割れを引き起こ す最も大きな要因と言われており, その特性が多くの研究者によっ て研究され，乾燥収縮予測式が数多く提案されている7) 10)。しかし ながら，普通コンクリートの予測式をポーラスコンクリートにその まま適用できないことから，限られた調合および使用材料の範囲で はあるが，筆者らは既にポーラスコンクリートの乾燥収縮の予測に 関寸る実験式を提案した ${ }^{3)}$ 。これに対して, 本報では, より広範囲 の調合および使用材料を用いた乾燥収縮試験を行うとともに，その 結果に基づいたより汎用性の高い理論モデルを構築することを試み る。

\footnotetext{
* 三重大学大学院工学研究科建築学専攻 大学院生 $\cdot$ 工修

** 三重大学大学院工学研究科 准教授・博士 (工学)

*** 三重大学大学院工学研究科 教授 $\cdot$ 工博
}

\section{2. 乾燥収縮試験}

\section{1 試験の概要}

後の第 3 章の理論モデルの構築において, 既報 3) の乾燥収縮試験 の結果も今回の試験結果と併せて使用寸るため，既報 3 )の内容につ いても「試験 I」として適宜記載する。なお,「試験 II」は新規で行 った試験であり, 特に断らない限り, 以下の記述は「試験 II」に関 するものである。

\section{（1）要因と水準}

表 1 に試験 I および II の要因と水準を示す。試験 I では，目標空 隙率および結合材の水セメント比を要因として基礎的な検討を行っ た。その結果，同種の骨材を用いた場合，ポーラスコンクリートの 最終乾燥收縮率は，目標空隙率が大きいほど小さくなったが，結合 材の水セメント比による影響は明確ではなかった ${ }^{3)}$ 。試験 II では, 試験 I の結果をより汎用性のあるものとするために, 要因として骨 材の岩種, 粒径および骨材表面の石粉の有無を取り上げた。さらに, 締固め状態により硬化体の特性が大きく異なるというポーラスコン クリートの特徵を考慮し, 同一調合のポーラスコンクリートに対し て 2 種類の締固め方法を採用し，その影響を確認した。

\section{(2) 調合および使用材料}

骨材の岩種などの影響を検証するために，全ての供試体の目標空 隙率および結合材の水セメント比を基本水準（目標空隙率：20\%, W/C：30\%）で一定とした。調合表および空隙率，圧縮試験の結果 を表 2 に示す。花崗閃緑岩 6 号の調合は,「骨材表面の石粉有り」 および「軽盛り+コテ仕上げ」の供試体に用いた。

表 3 に，使用した骨材の種類および骨材試験の結果を示す。本試 
表 1 乾燥収縮試験の要因と水準

\begin{tabular}{|c|c|c|}
\hline 試験 & 要因 & 水準 (下線は基本水準) \\
\hline \multirow{2}{*}{$\mathrm{I}^{3)}$} & 目標空隙率 & $15 \%, \quad 20 \%, \quad 30 \%$ \\
\hline & $\mathrm{W} / \mathrm{C}$ & $25 \%, \quad \underline{30 \%}, \quad 35 \%$ \\
\hline \multirow{4}{*}{ II } & 岩種 & 花崗閃緑岩, 石灰岩, 砂岩, 安山岩, 再生骨材 \\
\hline & 骨材の粒径 & $\begin{array}{l}6 \text { 号 }(5 \sim 13 \mathrm{~mm}), 7 \text { 号 }(2.5 \sim 5 \mathrm{~mm}), \\
8 \text { 号 }(1.2 \sim 2.5 \mathrm{~mm})\end{array}$ \\
\hline & $\begin{array}{l}\text { 骨材表面の } \\
\text { 石粉の有無 }\end{array}$ & 無し, 有り (石粉の付着量 1.1\%) \\
\hline & 締固め方法 & 棒突き+表面振動機, 軽盛り+コテ仕上げ \\
\hline
\end{tabular}

表 3 試験 II の骨材の試験結果

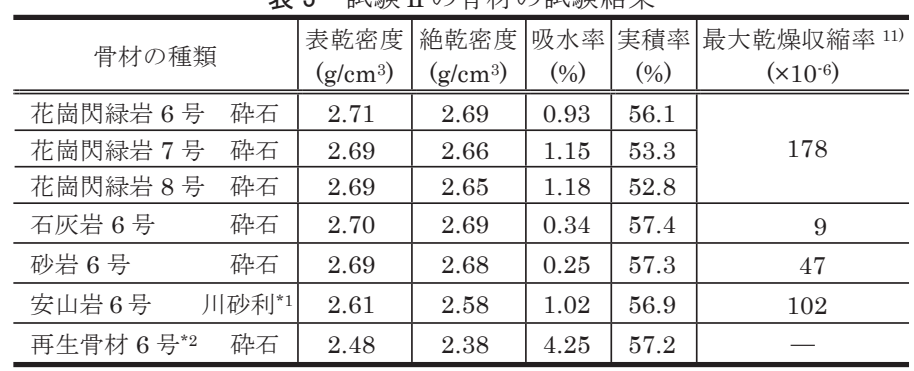

[注] *1 粉砕した川砂利

*2 原コンクリートの水セメント比は $79 \%$, 乾燥収縮率は不明
表 2 試験 II の調合表および試験結果

\begin{tabular}{|c|c|c|c|c|c|c|}
\hline \multirow[t]{2}{*}{ 骨材の種類 } & \multicolumn{3}{|c|}{ 単位量 $\left(\mathrm{kg} / \mathrm{m}^{3}\right)$} & \multirow{2}{*}{\begin{tabular}{|c} 
高性能 $\mathrm{AE}$ 減水剤 \\
$\left(\mathrm{g} / \mathrm{m}^{3}\right)$
\end{tabular}} & \multirow{2}{*}{\begin{tabular}{|c|}
$\begin{array}{c}\text { 実測空隙率 } \\
(\%)\end{array}$ \\
\end{tabular}} & \multirow{2}{*}{$\begin{array}{c}28 \text { 日圧縮強度 } \\
(\mathrm{MPa})\end{array}$} \\
\hline & $\mathrm{W}$ & $\mathrm{C}$ & $\mathrm{G}$ & & & \\
\hline 花崗閃緑岩 6 号 & 116 & 388 & 1523 & 375 & $20.2(31.5)$ & $22.6(6.9)^{* 1}$ \\
\hline 花崗閃緑岩 7 号 & 130 & 434 & 1431 & 677 & 23.8 & 19.1 \\
\hline 花崗閃緑岩 8 号 & 132 & 441 & 1419 & 921 & 21.3 & 18.3 \\
\hline 石灰岩 6 号 & 110 & 367 & 1547 & 355 & 16.5 & 23.8 \\
\hline 砂岩 6 号 & 111 & 370 & 1538 & 357 & 18.8 & 22.5 \\
\hline 安山岩 6 号 & 112 & 375 & 1487 & 362 & 19.1 & 22.2 \\
\hline 再生骨材 6 号 & 111 & 371 & 1418 & 358 & 20.7 & 15.9 \\
\hline
\end{tabular}

[使用材料］ セメント：普通ポルトランドセメント（密度 $3.17 \mathrm{~g} / \mathrm{cm}^{3}$ ) 高性能 $\mathrm{AE}$ 減水剂：ポリカルボン酸系

[注］*1 括弧内は「軽盛り+コテ仕上げ」で締め固めた供試体，その他は「棒 突き+表面振動機」で締め固めた供試体の圧縮強度を示す。
表 4 試験 II の流れ

\begin{tabular}{l|l|l}
\hline 材齢 $($ 日 $)$ & \multicolumn{1}{|c}{ 養生状態 } & \multicolumn{1}{c}{ 作業内容 } \\
\hline \hline 1 & 型枠内養生 & 脱型 \\
\hline $1 \sim 12$ & 水中養生 $^{* 1}$ & 空隙率の測定、キャッピング等 \\
\hline $12 \sim 19$ & 室内養生 $^{* 2}$ & 1 日毎に長さの測定 \\
\hline $19 \sim 61$ & 室内養生 & 1 週間毎に長さの測定 \\
\hline $61 \sim 75$ & 室内養生 & 2 週間毎に長さの測定 \\
\hline 75 以降 & 室内養生 & 1 ケ月毎に長さの測定 \\
\hline
\end{tabular}

[注］*1 空隙率の測定・キャッピングなどのため, 実際の水中養生 期間は 9 日以内。

*2 温度: $20^{\circ} \mathrm{C}$. 相対湿度: $60 \%$ の恒温恒湿室内にて気中養生。

験では，「骨材表面の石粉有り」の供試体を除き， 骨材を水洗いしてその表面に付着した石粉を除去 して用いた。ここで, 使用した骨材の最大乾燥収 縮率については，寺西 ${ }^{11)}$ が測定した乾燥期間 14 日の乾燥収縮率（5 個の平均值）を用いている。

\section{（3）供試体の作製}

供試体は, JIS A 1129 に従って, 各水準につき, 長さ測定用角柱供試体 $100 \times 100 \times 400 \mathrm{~mm}$ を 3 本, 圧縮試験用円柱供試体 $\phi 100 \times 200 \mathrm{~mm}$ を 6 本ず つ作製した。「棒突き+表面振動機」で締め固めた 供試体は, 2 層に分けて型枠に詰め, 各層ごとに 棒突きを行い, 最後に表面振動機（振動部の質量 $4 \mathrm{~kg}$ ，モータの回転数 $8000 \mathrm{rpm}$ ) で 10 秒間締固 めを行った。「軽盛り+コテ仕上げ」の供試体は, 型枠に試料を軽く詰めてコテで表面を均した。

\section{(4) 試験方法}

供試体の長さ変化の測定は, JIS A 1129-2 のコンタクトゲージ法 で行い, 長さ測定用角柱供試体は, 試験 I と同様な方法でキャッピ ングなどの処理を行った ${ }^{3)}$ 。表 4 に試験の流れを示す。供試体は脱 型した後, 空隙率の測定やキャッピングなどの作業を行いつつ, 材 齢 12 日まで水中養生 (水温 $20^{\circ} \mathrm{C}$ ) を行った。供試体の乾燥養生 (温 度 $20^{\circ} \mathrm{C}$, 相対湿度 $60 \%$ ）および長さ変化の測定は, 材齢 12 日目か ら開始し, 乾燥期間 154 日まで行った。ポーラスコンクリートの乾 燥期間 154 日までの乾燥収縮率は，3 本の供試体の測定值とその平 均值の差が最大で $43 \times 10^{-6}$ (全収縮率の $9 \%$ ）程度となった。この ため, 以下の考察では，3 本の供試体による平均值を用い，また， 乾燥期間との関係を示寸場合を除き, 乾燥収縮率および質量変化率 の值としては絶対値を用いる。

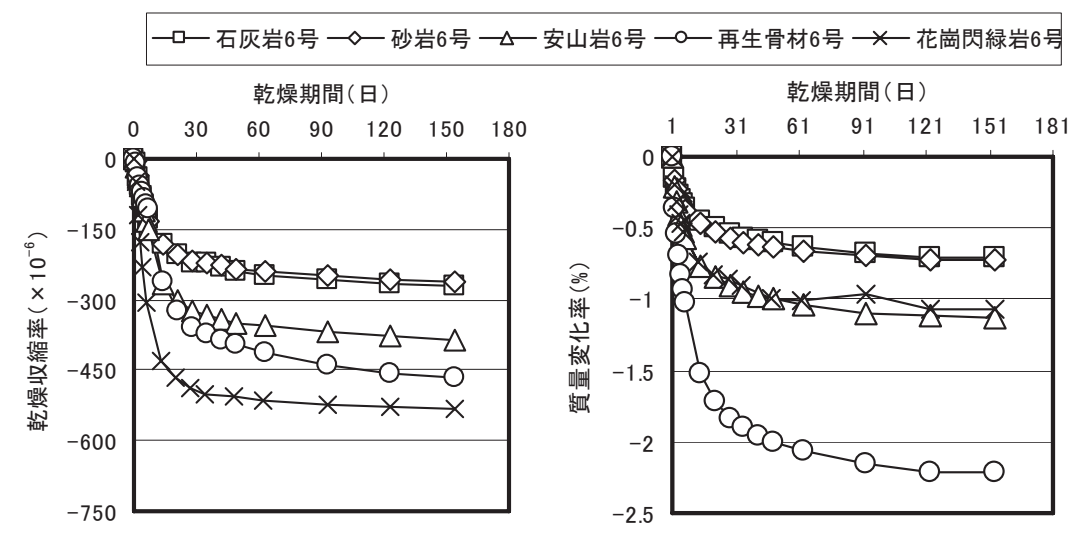

（a）乾燥収縮率

(b) 質量変化率

図 1 ポーラスコンクリートの乾燥収縮率と質量変化率に及 ぼす骨材の岩種の影響(目標空隙率 : 20\%, W/C : 30\%)

\section{2 試験結果および考察}

\section{(1) 骨材の岩種の影響}

ポーラスコンクリートの乾燥収縮率および質量変化率に及ぼす 骨材の岩種の影響を図 1 に示す。供試体の水中養生を終了した乾燥 材齢 0 日の時点では, 供試体の空隙に残った水により, 質量変化率 に誤差が生じると考えられるため，本論では乾燥材齢 1 日目に測定 した質量を質量変化率の始点質量とした。

図 1 (a) の乾燥収縮曲線と図 1 (b) の質量変化曲線の並ぶ順番を比 べると，乾燥収縮が大きいポーラスコンクリートの方が，必ずしも 質量変化が大きいということではない。これに対し，図 1 の比較に 用いたポーラスコンクリートの供試体は，乾燥収縮率と骨材の乾燥 収縮率の間（図 2), および質量変化率と骨材の吸水率の間（図 3) 
に，それぞれ良い相関関係を示した。

\section{（2）締固め方法の影響}

ポーラスコンクリートの乾燥収縮率および質量 変化率に及ぼす締固め方法の影響を図 4 に示す。

「棒突き十表面振動機」および「軽盛り+コテ仕上 げ」で締め固めた供試体は, 図中に示したように, 実測空隙率で $14 \%$ 程度, 材齢 28 日の圧縮強度で $16 \mathrm{MPa}$ 程度の差が生じたものの, 乾燥収縮率は 最終的にほぼ同じとなった。

以下，その理由について考察する。

図 5(a)〜 (c) は，それぞれ締固めの強弱による ポーラスコンクリートの供試体の断面, 球体で概 念的に表わした骨材粒子の配列，および材料の容 積比を図示したものである。ポーラスコンクリー トが，骨材と結合材による固相および気相から成 るものと考えれば，締固めが強いほど，固相部分 の容積率が大きく, 気相部分の容積率 (空隙率) が小さくなる〔図 5(a), (b)〕。

ここで，体積変化や力の伝達は固相のみで発生 し, 気相は寄与していない点を考慮すると, 固相 は乾燥収縮の測定方向に対して直列に, 気相は並 列に配置して考えることができる〔図 5 (c)〕。均 等に練り混ぜた結合材と骨材は, 容積比が一定の 状態で型枠に詰められる。締固め方法により骨材 粒子の配列が変わる[図 5(b)]ものの, 固相部分 における結合材と骨材の容積比 $(p / g)$ は変わら ない〔図 5(c)]ため, ポーラスコンクリートの乾 燥収縮率も変わらないと考えられる。

ただし，既報 3)では，目標空隙率が大きくなる ほど最終乾燥収縮率は小さくなるという結果が得 られた。この試験では, 目標空隙率を調節する目 的で結合材の量を変化させており, 結合材と骨材 の容積比 $(p / g)$ が大きいほど, ポーラスコンク リートの乾燥収縮率が大きくなることの影響が現 れていると考えられる。

\section{（3）骨材の粒径の影響}

ポーラスコンクリートの乾燥収縮率および質量 変化率に及ぼす骨材の粒径の影響を図 6 亿示す。 図 6 (a)によれば, ポーラスコンクリートの乾燥収 縮率は，骨材の粒径が小さいほど大きくなる傾向 が見られる。

図 6 の比較に用いたポーラスコンクリートは, 同じ目標空隙率で作られたものであり，骨材（花 崗閃緑岩 6 号, 7 号, 8 号) の実積率が粒径の増 大とともに大きくなるため(表 3), 結合材と骨材の容積比 $(p / g$, 後掲の表 5 参照）は，骨材の粒径が大きいほど小さくなる。上記の 締固め方法の影響に関する検討では, ポーラスコンクリートの乾燥 収縮率は, 結合材と骨材の容積比（ $p / g)$ が大きいほど大きくなる という考え方を示した。したがって, 図 6 (a) に見られる乾燥収縮率 の違いの 1 つの原因としては $p / g$ の影響が挙げられる。それ以外

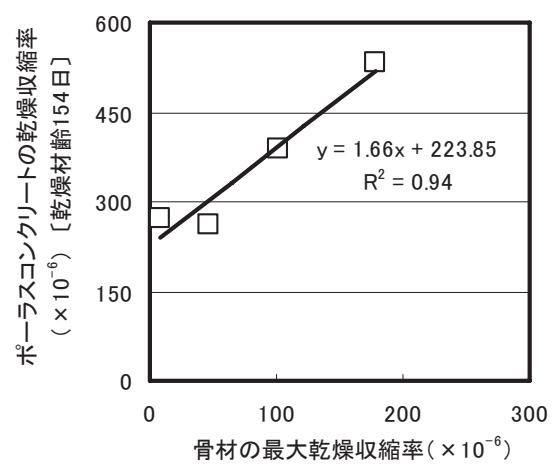

図 2 骨材の乾燥収縮率とポーラスコ ンクリートの乾燥収縮率の関係

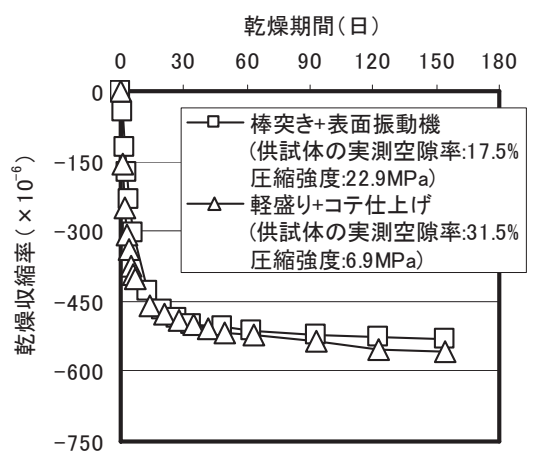

（a）乾燥収縮率

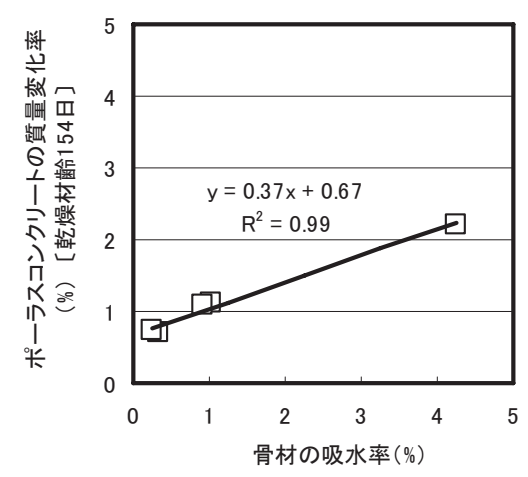

図 3 骨材の吸水率とポーラスコン クリートの質量変化率の関係

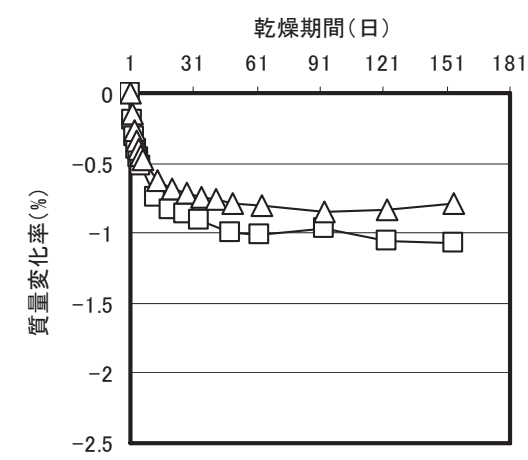

(b) 質量変化率
図 4 締固め方法の影響(骨材 : 花崗閃緑岩 6 号, 目標空隙率 : $20 \%, \mathrm{~W} / \mathrm{C}: 30 \%)$

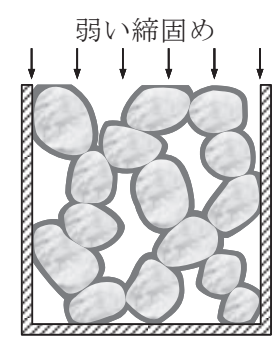

強い締固め

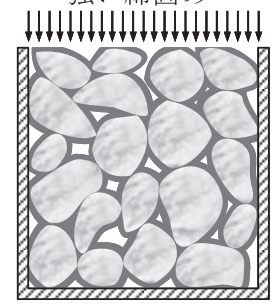

(a) 供試体の断面
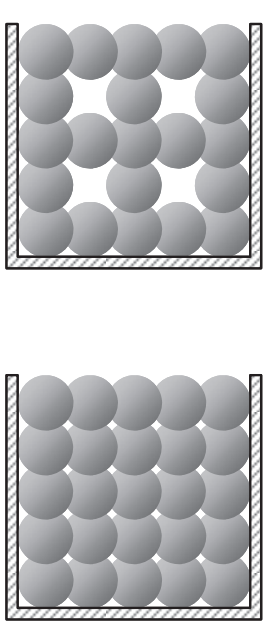

(b) 骨材粒子の配列イメージ

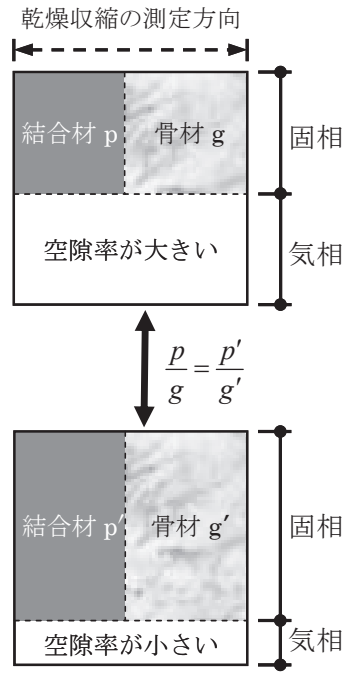

(c) 材料の容積
図 5 締固めによる骨材の配列と容積比の変化（一定）

にも，骨材の粒径が変わった場合の骨材粒子の収縮率，結合材の付 着状況, 骨材粒子の形状の影響なじも考えられるが, 現段階では, 詳細は不明である。

図 6 (c) および (d)によれば, 乾燥養生の初期段階において, 骨材 粒径が小さいポーラスコンクリートは，乾燥収縮の進行が緩やかで あり〔図 6(c)〕, 質量変化の進行が速やかであった〔図 6(d)〕。これ 
は, 水中養生を終了した後, 供試体の空隙に残っ た養生水の量は, 骨材の粒径が小さいほど多いこ と, 即ち, 小粒径ポーラスコンクリートの保水性 が高いことに起因すると考えられる。その結果と して, 図 6(b)によれば, 8 号骨材の供試体は最終 の質量変化率が非常に大きくなっている。

\section{（4）石粉の影響}

ポーラスコンクリートの乾燥収縮率および質量 変化率に及ぼす石粉の影響を図 7 に示寸。骨材の 表面に石粉（質量比で $1.1 \%$ ）が付着した供試体の 乾燥収縮率および質量変化率の曲線は, 表面に石 粉が付着していない場合の供試体とほぼ一致した。 したがって, ポーラスコンクリートの乾燥収縮に おいて, 骨材の表面に付着する石粉の影響は小さ いと考えられる。

\section{3. ポーラスコンクリートの乾燥収縮特性の幾 何学モデル}

\section{1 幾何学モデルの概要}

ここでは，骨材粒子を理想球体と仮定し，粒子 の配列および結合材の膜厚などの幾何学的な形状 をパラメータとして, ポーラスコンクリートの乾 燥収縮特性を検討する。

既往の研究 12) 15) では，ポーラスコンクリート の諸特性を議論する際, 幾何学モデルが用いられ ている。幾何学モデルの利点として, ポーラスコ ンクリート中の空隙構造および構成要素（骨材, 結合材，空隙）の分布の影響を考慮しながら議論 できることが挙げられる。一方で，実際にはラン ダムに配列している骨材を一定の配列と仮定寸る 際の根拠が問題となる。これに対して本報では, 第 2 章で示した試験結果から, 締固めの程度によ らず, 固相内の材料の容積比 $p / g$ により乾燥収縮 率が一義的に決定されることを示した。ただし，

実際のポーラスコンクリートの乾燥収縮に対しては, 結合材のうち 骨材間の接合部付近に存在するもののみが寄与すると考えられ, 調 合上の $p / g$ をそのまま収縮率の推定に用いることはできない。

本研究では, この結合材の影響評価を含め, 簡易かつ汎用的な乾 燥収縮予測モデルを構築することを試みる。以下，ポーラスコンク リートの乾燥収縮特性を表現するための幾何学モデルについて検討 する。

\section{（1） 材料の分布状態と容積の関係}

幾何学モデルの基本的仮定条件として，以下を設定する。

i ）骨材粒子は，使用骨材の平均粒径を持つ理想球体である。

ii）練混ぜの段階において, 結合材が均等に混ぜられる。

iii ）結合材が理想球体の表面に均一の膜厚で付着する。

図 8 に, 練混ぜの段階における 1 個の理想球体とその表面に付着 する結合材の分布状態を示す。なお, 図中にはそれぞれの容積 $\left(V_{g}\right.$, $\left.V_{p}\right)$ の計算式を併示してある。ここでは, モデルにおける 1 個の理
乾燥期間 (日) $\begin{array}{llllll}30 & 60 & 90 & 120 & 150 & 180\end{array}$

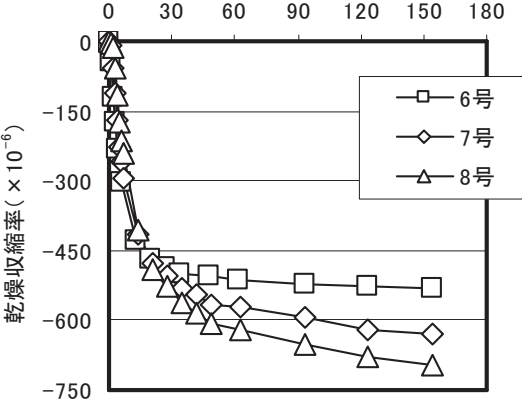

（a）乾燥収縮率

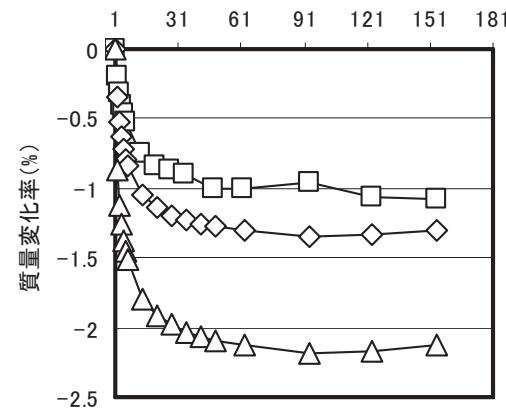

(b) 質量変化率 181
乾燥期間（日）〔対数軸〕

10 100

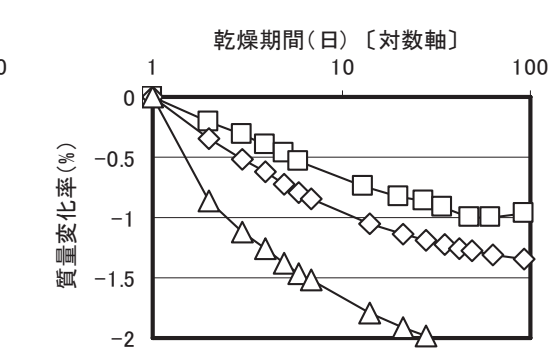

（d）初期の質量変化率

（c）初期の乾燥収縮率
図 6 骨材の粒径の影響(岩種 : 花崗閃緑岩, 目標空隙率 : $20 \%, \mathrm{~W} / \mathrm{C}$ : $30 \%$ )

乾燥期間 (日)

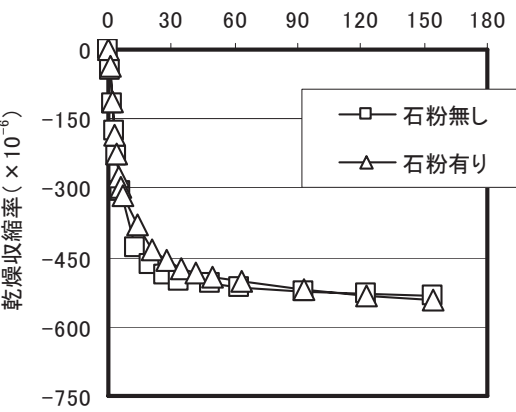

（a）乾燥収縮率

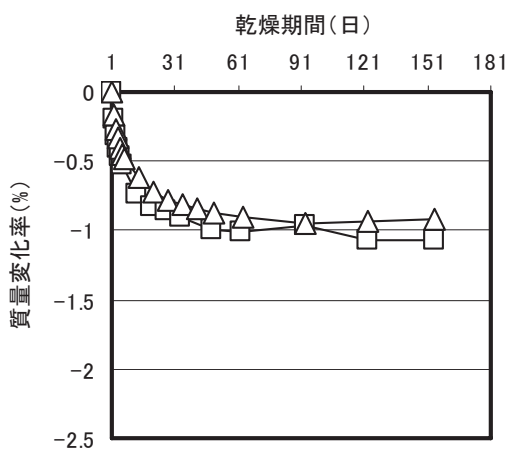

(b) 質量変化率
図 7 石粉の影響(骨材：花崗閃緑岩 6 号，目標空隙率：20\%，W/C : $30 \%)$

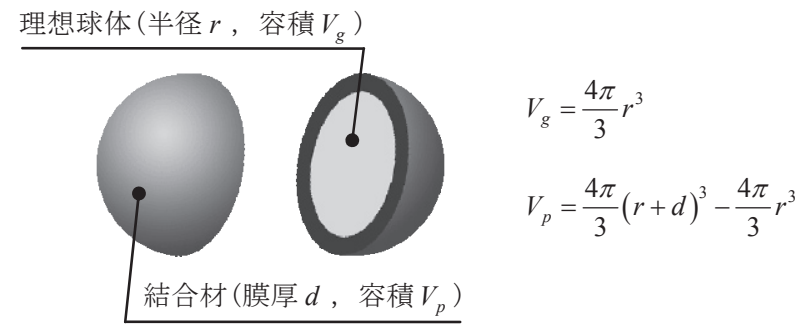

図８＼cjkstart理想球体の骨材と結合材の分布

想球体とその表面に付着する結合材との容積比として, 以下の式 (1) のように，調合設計時の結合材と骨材の単位容積比を用いることと する。式(1)の導入により, ポーラスコンクリートの乾燥収縮に及ぼ 寸調合条件の影響，および結合材と骨材との容積比が締固め方法に よって変わらないとする試験結果を反映することができる。 


$$
\frac{V_{p}}{V_{g}}=\frac{p}{g}
$$

ここに, $V_{g}:$ 理想球体の容積 $\left(\mathrm{mm}^{3}\right)$,

$V_{p}$ : 理想球体に付着寸る結合材の容積 $\left(\mathrm{mm}^{3}\right)$,

$p:$ 結合材の単位容積 $\left(\mathrm{m}^{3} / \mathrm{m}^{3}\right)$,

$g$ : 骨材の単位容積 $\left(\mathrm{m}^{3 /} \mathrm{m}^{3}\right)$

\section{（2）理想球体の表面距離}

本研究では, 収縮する際, 個々の理想球体が互いに接 近して距離を縮めることを想定し, 理想球体の中心距離 を基準とした長さ変化率を用いて, ポーラスコンクリー 卜の乾燥収縮率を算定する。

打込みの段階において，骨材同士はその間の結合材を 隙間の外へ押し出しながら, 互いに接近する。その状態 からの乾燥収縮のメカニズムを図 9 に示す。隣接する骨 材粒子は, 自身が収縮するほか, その表面をつなぐ結合 材の収縮によって引っ張られて互いに近づく。骨材粒子 の形状, 結合材の分布状態などの影響で, 骨材粒子間の 距離変化は不均一であり, ポーラスコンクリートの乾燥 収縮率には，その不均一な収縮が総合的に反映されるも のと考えられる。

ここでは, 骨材粒子の形状などの影響を総合的に表す係数として, 結合材の膜厚 $d$ に対寸る倍率 $n$ を導入し, 図 10 に示すような, 骨 材粒子間に厚さ $n \cdot d$ の結合材が存在するモデルに置き換えて評価 を行う。ここで倍率 $n$ は, 骨材粒子の表面距離と結合材の膜厚との 幾何学関係を直接表わしたものではないことに留意されたい。

\section{（3）理想球体の配列と乾燥収縮の関係}

図 10 の幾何学関係を持つ 2 個の理想球体の乾燥収縮について図 11 (a) の座標で考える。中心点 $\mathrm{A}, \mathrm{B}$ の距離, $X$ 軸方向, $Y$ 軸方向 の距離をそれぞれ $l, l_{x}, l_{y}$, 長さ変化量をそれぞれ $\Delta l, \Delta l_{x}, \Delta l_{y}$, 長さ変化率をそれぞれ $\varepsilon, \varepsilon_{x}, \varepsilon_{y}$ と寸れば, 3 つの方向の長さ変化 率は等しい。すなわち,

$$
\varepsilon=\varepsilon_{x}=\varepsilon_{y}
$$

$$
\text { ここに，長さ変化率 : } \varepsilon=\frac{\Delta l}{l}, \quad \varepsilon_{x}=\frac{\Delta l_{x}}{l_{x}}, \quad \varepsilon_{y}=\frac{\Delta l_{y}}{l_{y}}
$$

$$
\text { 各方向の比例関係 : } \frac{\Delta l}{l}=\frac{\Delta l_{x}}{l_{x}}=\frac{\Delta l_{y}}{l_{y}}
$$

複数粒子の配列を示した図 11 (b) について考える。理想球体の中 心 $\mathrm{A}$ から $\mathrm{S}$ までの順番で, 理想球体の中心点を繋ぐ線分 $\mathrm{A}-\mathrm{B}, \mathrm{B}-\mathrm{C}$, $\mathrm{C}-\mathrm{D} \cdots \mathrm{Q}-\mathrm{R}, \mathrm{R}-\mathrm{S} の X$ 軸方向の距離をそれぞれ $l_{x 1}, l_{x 2}, l_{x 3} \cdots l_{x n-1}$, $l_{x n}$, 長さ変化量をそれぞれ $\Delta l_{x 1}, \Delta l_{x 2}, \Delta l_{x 3} \cdots \Delta l_{x n-1}, \Delta l_{x n}$ とすれ ば, 中心点 $\mathrm{A}, \mathrm{S} の X$ 軸方向の距離 $L_{x}$, 長さ変化量 $\Delta L_{x}$, 長さ変 化率 $\varepsilon_{(A \sim S) x}$ は, 以下のように計算できる。

$$
\begin{aligned}
& \varepsilon_{(A \sim S) x}=\frac{\Delta L_{x}}{L_{x}}=\frac{\Delta l_{x 1}+\Delta l_{x 2}+\cdots+\Delta l_{x n}}{l_{x 1}+l_{x 2}+\cdots+l_{x n}} \\
& こ こ に, \quad L_{x}=l_{x 1}+l_{x 2}+\cdots+l_{x n} \\
& \Delta L_{x}=\Delta l_{x 1}+\Delta l_{x 2}+\cdots+\Delta l_{x n}
\end{aligned}
$$

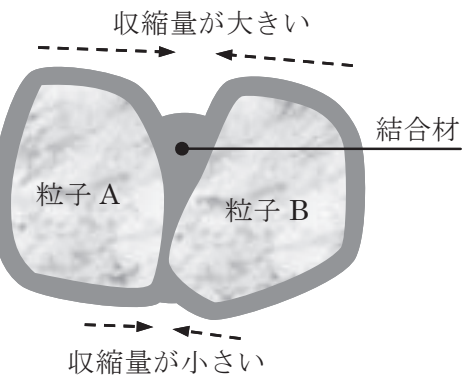

図 9 材料の分布と乾燥収縮の関係

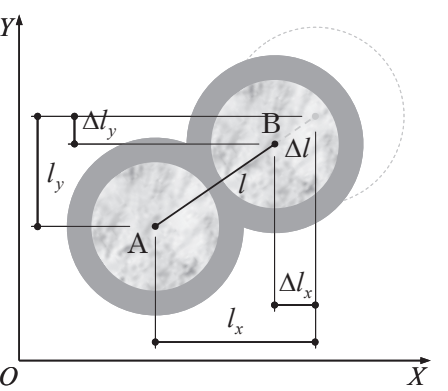

（a）2粒子の場合

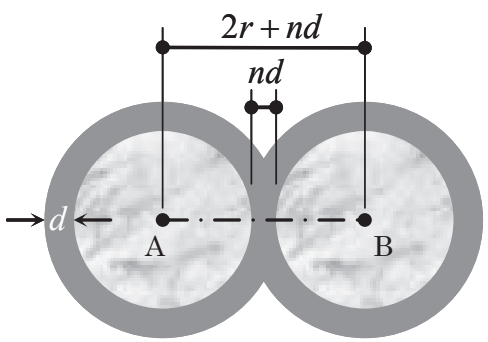

図 10 乾燥収縮特性の幾何学モデル

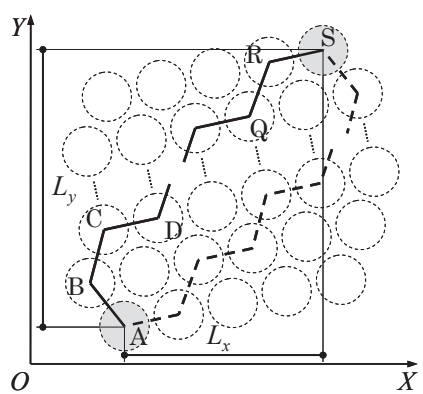

(b) 複数粒子の場合
図 11 理想球体の配列と乾燥収縮の関係

図 11 (b)の配列において, 隣接する理想球体が同じ中心距離 $l$ とな る場合，それぞれの中心距離を基準とした中心軸方向の長さ変化率 $\varepsilon, X$ 軸方向の長さ変化率 $\varepsilon_{x}$ がすべて等しいため, $\varepsilon_{(A \sim S) x}$ と $\varepsilon$ の関 係は以下のようになる。

$$
\begin{aligned}
\varepsilon_{(A \sim S) x} & =\frac{\varepsilon\left(\Delta l_{x 1}+\Delta l_{x 2}+\cdots+\Delta l_{x n}\right)}{\varepsilon\left(l_{x 1}+l_{x 2}+\cdots+l_{x n}\right)} \\
& =\frac{\varepsilon\left(\Delta l_{x 1}+\Delta l_{x 2}+\cdots+\Delta l_{x n}\right)}{\Delta l_{x 1}+\Delta l_{x 2}+\cdots+\Delta l_{x n}} \\
& =\varepsilon \\
\text { ここに, } \quad \varepsilon & =\varepsilon_{x}=\frac{\Delta l_{x 1}}{l_{x 1}}=\frac{\Delta l_{x 2}}{l_{x 2}}=\cdots=\frac{\Delta l_{x n}}{l_{x n}}
\end{aligned}
$$

図 11 (b)に示寸破線のルートを用いて考える場合でも, 以上と同 様な結果が得られる。そのほか, 配列が変わる場合, 又は, $Z$ 軸を 入れて 3 次元で考察する場合でも, 幾何学モデルの配列にかかわら ず，任意の 2 個の理想球体の間の乾燥収縮率は，隣接の理想球体の 中心軸方向の乾燥収縮率と等しいことが, 同様な手法で証明できる。

\section{2 幾何学モデルに基づくポーラスコンクリートの乾燥収縮率}

前節では, 乾燥収縮特性の幾何学モデルに関して定性的に検討し, ポーラスコンクリートの乾燥収縮率は, 図 10 に示す 2 個の理想球 体を並べる形でモデル化することができることを示した。同図に示 す幾何学関係によれば，中心距離を基準とする収縮量は，骨材およ び結合材の乾燥収縮量の合計となり，ポーラスコンクリートの乾燥 収縮率は, その収縮量を理想球体の中心距離 $2 r+n d$ で割る形式で計 算できる。すなわち, 
表 5 ポーラスコンクリートの計算条件と最終乾燥収縮率

\begin{tabular}{|c|c|c|c|c|c|c|c|}
\hline \multirow[b]{2}{*}{ 骨材の種類 } & \multirow{2}{*}{$\begin{array}{c}\text { 目標 } \\
\text { 空隙率 } A \\
\quad(\%)\end{array}$} & \multirow{2}{*}{$\begin{array}{l}\mathrm{W} / \mathrm{C} \\
(\%)\end{array}$} & \multirow{2}{*}{$\begin{array}{l}\text { 結合材と骨材の } \\
\text { 単位容積比 } p / g\end{array}$} & \multirow{2}{*}{$\begin{array}{c}\text { 結合材の } \\
\text { 乾燥収縮率 } \varepsilon_{p} \\
\left(\times 10^{-6}\right)\end{array}$} & \multirow{2}{*}{$\begin{array}{c}\text { 骨材の } \\
\text { 乾燥収縮率 } \varepsilon_{g}{ }^{*} 1 \\
\left(\times 10^{-6}\right)\end{array}$} & \multicolumn{2}{|c|}{ ポーラスコンクリートの乾燥収縮率 } \\
\hline & & & & & & $\begin{array}{c}\text { 推定結果(倍率 } n=1) \\
\left(\times 10^{-6}\right)\end{array}$ & $\begin{array}{l}\text { 測定結果 }{ }^{* 2} \\
\left(\times 10^{-6}\right)\end{array}$ \\
\hline 花崗閃緑岩 6 号 & 15 & 30 & 0.515 & 2228 & 178 & 310 & ב567 \\
\hline 花崗閃緑岩 6 号 & 20 & 25 & 0.426 & 2038 & 178 & 272 & 548 \\
\hline 花崗閃緑岩 6 号 & 20 & 30 & 0.426 & 2228 & 178 & 291 & $532,558^{* 3}, 541^{* 4}$ \\
\hline 花崗閃緑岩 6 号 & 20 & 35 & 0.426 & 2528 & 178 & 327 & 606 \\
\hline 花崗閃緑岩 6 号 & 30 & 30 & 0.248 & 2228 & 178 & 248 & 473 \\
\hline 花崗閃緑岩 7 号 & 20 & 30 & 0.501 & 2228 & 178 & 307 & 631 \\
\hline 花崗閃緑岩 8 号 & 20 & 30 & 0.515 & 2228 & 178 & 310 & 697 \\
\hline 石灰岩 6 号 & 20 & 30 & 0.394 & 2228 & 9 & 124 & 272 \\
\hline 砂岩 6 号 & 20 & 30 & 0.396 & 2228 & 47 & 160 & 263 \\
\hline 安山岩 6 号 & 20 & 30 & 0.406 & 2228 & 102 & 215 & 387 \\
\hline
\end{tabular}

[注］ *1 参考文献 11)参照 *2 乾燥材齢 154 日 *3「軽盛り+コテ仕上げ」で締め固めた供試体 *4 骨材表面に石粉が付着した供試体

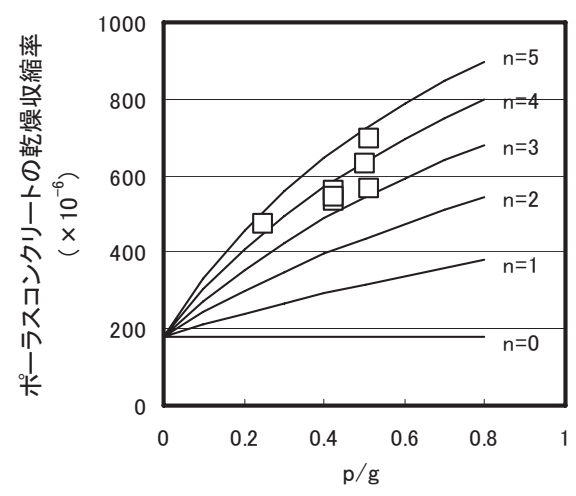

（a）単位容積比の影響 $\left(\varepsilon_{g}=178 \times 10^{-6}, \quad \varepsilon_{p}=2228 \times 10^{-6}\right)$

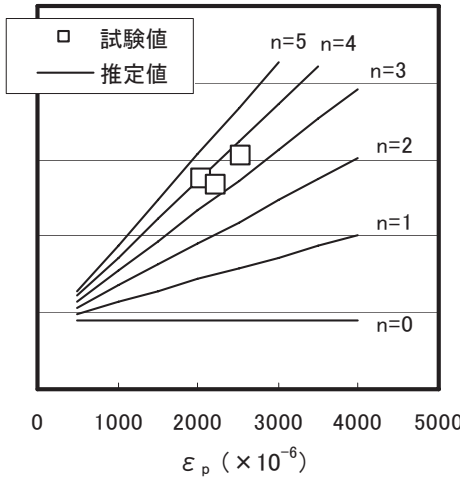

(b) 結合材の収縮率の影響

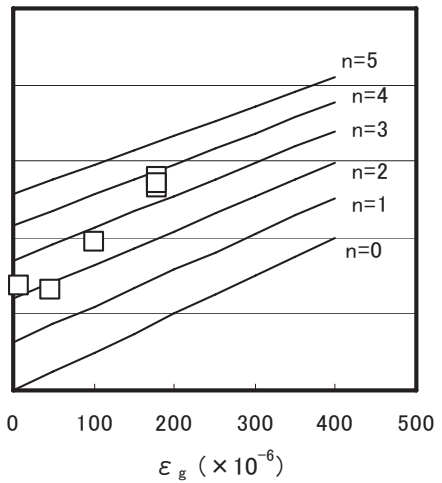

(c) 骨材の収縮率の影響

$\left(p / g=0.426, \varepsilon_{g}=178 \times 10^{-6}\right) \quad\left(p / g\right.$ の平均值 : $\left.0.405, \varepsilon_{p}=2228 \times 10^{-6}\right)$

図 12 推定結果と測定結果の比較

$$
\begin{aligned}
\varepsilon_{P O C \infty} & =\frac{n d \cdot \varepsilon_{p}+2 r \cdot \varepsilon_{g}}{2 r+n d} \\
& =\frac{n d}{2 r+n d} \cdot \varepsilon_{p}+\frac{2 r}{2 r+n d} \cdot \varepsilon_{g}
\end{aligned}
$$

ここに, $\varepsilon_{P O C \infty}:$ ポーラスコンクリートの最終乾燥収縮率 $\left(\times 10^{-6}\right)$,

$\varepsilon_{p}:$ 結合材の最終乾燥収縮率 $\left(\times 10^{-6}\right)$,

$\varepsilon_{g}$ : 骨材の最終乾燥収縮率 $\left(\times 10^{-6}\right)$,

$r$ : 理想球体の半径 $(\mathrm{mm})$,

$d$ : 結合材の膜厚 $(\mathrm{mm})$,

$n$ : 膜厚 $d$ に対する倍率

式(6)によれば, ポーラスコンクリートの乾燥収縮率は, 結合材お よび骨材によって生じるそれぞれの乾燥収縮率の合計で推定される。 ここでは, 式 (6) に結合材の膜厚と理想球体の半径の比 $k=d / r$ を導 入し, 膜厚 $d=k r$ を式(6)に代入すると,

$$
\begin{aligned}
& \varepsilon_{P O C_{\infty}}=\varepsilon_{P O C_{-} p}+\varepsilon_{P O C_{-} g} \\
& \varepsilon_{P O C_{-} p}=\frac{n k}{n k+2} \cdot \varepsilon_{p} \\
& \varepsilon_{P O C_{-} g}=\frac{2}{n k+2} \cdot \varepsilon_{g}
\end{aligned}
$$

ここに， $\varepsilon_{P O C \infty, p}$ : 結合材の乾燥収縮による乾燥収縮率 $\left(\times 10^{-6}\right)$, $\varepsilon_{P O C \infty_{-} g}$ : 骨材の乾燥収縮による乾燥収縮率 $\left(\times 10^{-6}\right)$, $k$ : 理想球体の半径 $r$ に対する結合材の膜厚 $d$ の比
また, 係数 $k$ と結合材および骨材の単位容積 $V_{p}, V_{g}$ の関係式は, 図 8 と式(1)から，以下のように得られる。すなわち, $V_{p}=\frac{4 \pi}{3}(r+d)^{3}-\frac{4 \pi}{3} r^{3}$ および $V_{g}=\frac{4 \pi}{3} r^{3}$ に $r=d / k$ を代入し, 式(1) を変形すると，

$$
\begin{aligned}
& \frac{p}{g}=\frac{V_{p}}{V_{g}}=(1+k)^{3}-1 \\
\therefore \quad k & =\left(\frac{p}{g}+1\right)^{1 / 3}-1
\end{aligned}
$$

\section{3 実測結果から求めた倍率 $n$ の值}

既述したように，倍率 $n$ に及ぼす骨材粒子の形状と材料の不均一 な分布の影響を定量評価するのは非常に難しい。このため, 本研究 では, 最終乾燥収縮率の推定結果と測定結果との比較から倍率 $n$ を 定める。ここで，測定結果に関しては乾燥材齢 154 日のデータを用 いる。ポーラスコンクリートの供試体の調合条件, 倍率 $n=1$ とした 推定結果，および乾燥収縮率の測定結果を表 5 に示す。

図 12 に, 調合要因ごとに倍率 $n$ を変化させた場合の推定結果と測 定結果の比較を示す。ポーラスコンクリートの乾燥収縮率の推定值 は, 結合材と骨材の単位容積比〔同図 (a) ], 結合材の乾燥収縮率〔同 図 (b)]，および骨材の乾燥収縮率〔同図 (c)〕のそれぞれの増大と共 に大きくなる傾向があり，定性的には，ポーラスコンクリートの乾 燥収縮に及ぼす目標空隙率，締固め程度，骨材の岩種などの影響を 
要因とした試験結果の傾向と一 致している。また, 倍率 $n$ の值 は，おおよそ 2〜5 の範囲にあ り, 試験值から逆算した倍率 $n$ の平均值は $n_{\text {ave }}=3.4$ となる。

\section{4 提案式による推定精度 の確認}

前節では, 調合上の結合材と 骨材の容積比を考慮した推定式 を提示した。ここで, 理想球体 の粒径 $2 r$ として, 実際に用い られる骨材の平均粒径を仮定す ると, 膜厚 $d=k r$ は, 調合条件 である $p / g$ の值から決定され ることから, 提案式の最終形〔式 （7）～式 (10)]には, 理想球体の 半径 $r$ が含まれない。このこと は, 本提案モデルでは, ポーラ スコンクリートの乾燥収縮が骨 材の平均粒径には影響されるも のの, 粒度分布によって変化し ないことを示している。

倍率 $n$ の值を $n_{\text {ave }}(=3.4)$ と して提案式に代入した場合の推 定結果と乾燥収縮試験の全ての 測定結果との比較を図 13 に示 す。 $n$ の值に平均值を用いても， おおむね良好な推定精度が得ら れていると言える。

\section{5 骨材と結合材の寄与率}

本提案式 [式(7)～式(10)]に よるポーラスコンクリートの乾 燥収縮率は, 図 10 の理想球体の中心距離 $\mathrm{AB}$ 間における結合材と骨 材の長さの比率（以下，重夕係数）に，各材料の収縮率を乗じたも のの合計として算定される。すなわち, 式(8) と式(9)における $\varepsilon_{p}$ と $\varepsilon_{g}$ に掛ける重み係数は, ポーラスコンクリート全体の乾燥収縮率に おける結合材および骨材の乾燥收縮率の重みを表している。

図 14 は, 両者の重み係数と $p / g$ の関係を示したものである。図 によれば，本試験の検討範囲では，骨材の収縮率の重み係数はほぼ 80\% 90\%と極めて高い。一方, 図 15 は, ポーラスコンクリート全 体の乾燥収縮率における両者の寄与率を示したものである。図によ れば, 本試験の検討範囲において, 結合材は骨材に比べ, 乾燥収縮 率が大きいため, ポーラスコンクリート全体の乾燥収縮率における 寄与率が，結合材の水セメント比〔同図(a)〕および骨材の岩種〔同 図(b)]によらず $60 \%$ 超えている。また，通常のポーラスコンク リート（目標空隙率が 15\%〜 30\%）では，結合材と骨材の単位容積 比 $p / g$ が, 本研究の検討範囲を大幅に超えることは少ない。このこ とから, 一般にポーラスコンクリートの乾燥収縮率は, 骨材よりも 結合材の乾燥収縮率に大きく依存すると言える。また, ポーラスコ

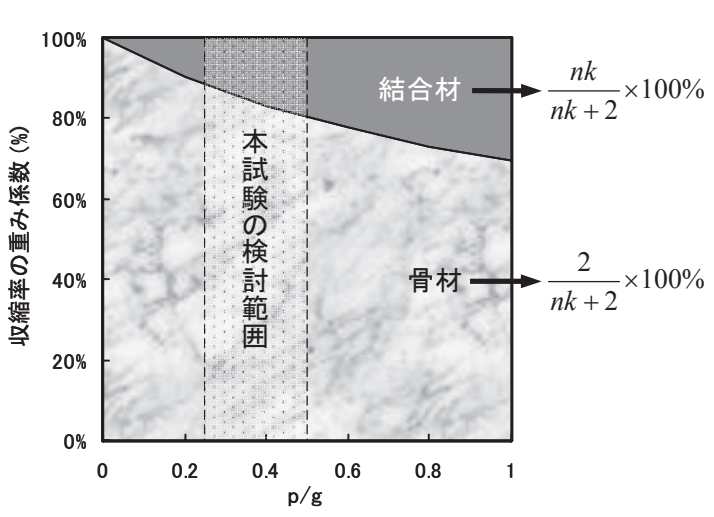

図 14 結合材と骨材の乾燥収縮率の重み係数 $(n=3.4)$

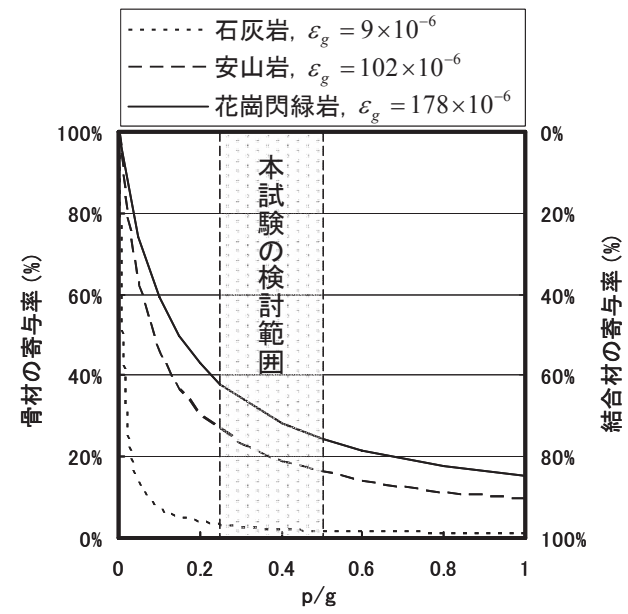

(b) 骨材の岩種の影響 $\left(\varepsilon_{p}=2228 \times 10^{-6}\right)$

，骨材の寄与率: $\frac{\varepsilon_{P O C_{\_} g}}{\varepsilon_{P O C_{n}}} \times 100 \%$ $\frac{\varepsilon_{P O C \infty}}{\varepsilon_{P O C}} \times 100 \%$, 骨材の奇与率: $\frac{\varepsilon_{P O C}}{\varepsilon_{P O C \infty}} \times 1$

与率 $(n=3.4)$ である〔同図 (a)参照〕のに対し, 骨材の種類の違いには比較的敏感 である〔同図 (b) 参照〕。

\section{4. 本研究のまとめ}

本研究では, ポーラスコンクリートの乾燥収縮試験を行い, その 基礎的な乾燥収縮特性に及ぼす諸要因の影響を検証した。さらに， その結果に基づいて乾燥収縮を予測するための幾何学モデルを提案 した。本研究の範囲において, 以下の知見が得られた。

1）ポーラスコンクリートの乾燥収縮率と骨材の乾燥収縮率の間, および質量変化率と骨材の吸水率の間には，それぞれ強い相関 関係がある。

2）ポーラスコンクリートの乾燥収縮率は, 締固め程度の影響をほ とんど受けない。

3）ポーラスコンクリートの乾燥収縮率は，骨材の粒径が小さいほ ど大きくなる傾向がある。

4）ポーラスコンクリートの乾燥収縮において, 骨材の表面に付着 
する石粉の影響は小さかった。

5）試験結果に基づき，以下の表 6 にまとめた乾燥収縮予測式を提 案した。

表 6 ポーラスコンクリートの乾燥収縮の推定式

$$
\begin{aligned}
& \varepsilon_{P O C_{\infty}}=\varepsilon_{P O C_{-} p}+\varepsilon_{P O C_{-} g} \\
& \varepsilon_{P O C_{-} p}=\frac{n k}{n k+2} \cdot \varepsilon_{p} \\
& \varepsilon_{P O C_{-} g}=\frac{2}{n k+2} \cdot \varepsilon_{g} \\
& k=\left(\frac{p}{g}+1\right)^{1 / 3}-1
\end{aligned}
$$

6）本研究で提案した幾何学モデルおよび乾燥収縮予測式は，定性 的には，ポーラスコンクリートの乾燥収縮に及ぼす目標空隙率， 締固め方法, 骨材の岩種などの影響を再現することができ, ま た定量的にもほぼ良好な推定精度が得られたと言える。

7）ポーラスコンクリートの乾燥収縮率は, 骨材よりも結合材の乾 燥収縮率に大きく依存すると言える。また，ポーラスコンクリ 一トの乾燥収縮率は, 結合材の水セメント比の変化には鈍感で あるのに対し，骨材の種類の違いには比較的敏感である。

なお, 本研究の理論モデルでは, 骨材の形状, 材料の不均一分布 などの影響が明確にされていない。また, 試験データが少ないため, 予測式の推定精度に関する検証は十分とは言えない。今後, 材料の 幾何学性状の影響を含めた検討や，より多くの試験データを用いた 検証が必要である。

\section{謝辞}

本研究で使用した骨材の取得に際して, 犬飼利嗣先生（岐阜工学 高等専門学校）の助力を得た。本研究費の一部は，日本技術振興会 科学研究費補助金 基盤研究(B)（研究代表者: 畑中重光）によった。 付記して謝意を表する。

\section{参考文献}

1） ポーラスコンクリートの設計・施工法に関する研究委員会報告書，日本コ ンクリート工学協会, p.231, 2003.5

2）張茂剛，三島直生，畑中重光：ポーラスコンクリートの乾燥収縮特性に 関する基礎的研究，日本建築学会大会学術講演梗概集（九州），A-1 材料 施工, pp. 845-846， 2007

3）張茂剛, 三島直生，畑中重光：ポーラスコンクリートの乾燥収縮特性と その予測式に関する研究, 日本建築学会構造系論文集, Vol.75, No.647, pp. 25-31, 2010.1

4）張茂剛，三島直生，畑中重光：ポーラスコンクリートの圧縮強度および 弾性係数に及ぼす乾燥養生の影響, 日本建築学会大会学術講演梗概集（北 陸），A-1 材料施工，pp. 1099-1100，2010

5）鄭木蓮，陳栓発，王秉綱：ポーラスコンクリートの収縮特性に関する研 究, 中国西安建築科学技術大学学報, Vol.37, No.4, pp.483-487, 2005.12

6）吉森和人，岡本亨久，下山善秀，堀口剛：植生ポーラスコンクリートの 製造と耐久性に関する実験的研究，エココンクリートの現状と将来展望に 関するシンポジウム, pp.39-46, 1995.11

7) Z.P.Bazant and L.Panula : Practical Prediction of Time-Dependent Deformation of Concrete, part I : Shrinkage, Materiaux et Constructions, Vol.11, No.65, pp. 307-316, 1978

8) ACI Committee 209 : Prediction of Creep, Shrinkage and Temperature Effects in Concrete Structures, ACI SP-76, pp. 193-300, 1982

9) 阪田憲次：コンクリートの乾燥収縮およびクリープの予測，コンクリート 工学, Vol.31, No.2, pp. 5-14, 1993.2

10）鉄筋コンクリート造建築物の収縮ひび割れ制御設計·施工指針（案），日 本建築学会, pp.53-60, pp.179-190, 2006

11）寺西浩司：骨材がコンクリートの乾燥収縮ひずみに及ぼす影響（その 1 . 実験計画および実験結果），日本建築学会大会学術講演梗概集（北陸）,

A-1 材料施工, pp. 929-930，2010

12）前川明弘, 畑中重光, 三島直生, 湯浅幸久 : ポーラスコンクリートの圧 縮強度一空隙率関係に関する実験とそのモデル化, 日本建築学会構造系論 文集，Vol.73，No.625，pp. 363-368，2008.3

13）大谷俊浩，村上聖，佐藤嘉昭，三井宜之，平居孝之：理想球形骨材によ るポーラスコンクリートモデル供試体の圧縮強度理論に関する研究，日本 建築学会構造系論文集，No.586，pp. 7-13，2004.12

14）松川嘾，玉井元治，杉浦善充：自然環境に優しい多孔質コンクリートの 緑化に関する研究，セメントコンクリート論文集，No.55，pp. 384-389, 2001

15）玉井元治：連続空隙を有する固化体の透水性，セメント技術年報, No.42, pp. $591-594,1988$ 